\title{
THE VALUE OF FIBULAR INTERSOMATIC FUSION IN THE TREATMENT OF RECENT CERVICAL SPINAL CORD INJURIES
}

\author{
By Alain. B. Rossier, M.D., Robert W. Hussey, M.D., John E. Kenzora, M.D., \\ Mehdi Sarkarati, M.D. and Jitendar M. SeThi, M.D. \\ Harvard Medical School, Spinal Cord Injury Service, West Roxbury Veterans \\ Administration Hospital, and Orthopaedic Department, Peter Bent Brigham Hospital, \\ Boston, Mass., U.S.A.
}

\begin{abstract}
A SERIES of six patients with recent cervical spine fracture and spinal cord injury treated by corpectomy and fibular strut graft is presented. Three patients had a complete sensorimotor tetraplegia and the other three had an incomplete sensory but complete motor lesion. All patients had fractures of one or two adjacent vertebrae with concomitant displacement which was corrected by skull traction prior to surgery. Gas myelography in three patients revealed herniated disc material in two instances. Corpectomy and fusion were carried out on the I2th, I 3 th, 29th, 32nd, 33rd, and the 58th post-traumatic day. There was no immediate mortality or major complication associated with the procedure. One late death in an elderly patient 6 months post-operatively is felt to be unrelated to the procedure. In this series gas myelography was carried out at a later date following the injury. The goal of the operation was therefore not primarily to decompress the cord but to stabilise the fractured spine in order to allow earlier mobilisation than traditional treatment in traction. Average time out of bed was 9 days post-operatively and 36 days post-injury. Solid fusion sufficient to allow discontinuation of all neck support was achieved in 3 months in all patients. There were no episodes of graft displacement or dislocation and in only one patient was there a moderate increase in angulation at the fracture site. In the patient who died 6 months postoperatively gross and histologic examinations showed incorporation and union at the ends of the graft and bridging of the injured area by new bone. The authors feel the above procedure in selected patients-six out of 62 patients admitted with cervical spine and spinal cord injury within 4 weeks of trauma during the past 39 months-is an important adjunct to the treatment and rehabilitation at their spine fracture and spinal cord injury.
\end{abstract}

Key words: Cervical spinal cord injuries; anterior cervical fusion; gas myelography.

\section{RÉSUMÉ}

Les auteurs présentent leurs résultats chez 6 tétraplégiques récents traités par corpectomie et spondylodèse antérieure par greffon péronier. Comparé au traitement classique par traction cervicale, ce type de stabilisation permit une mobilisation plus rapide des patients en fauteuil roulant, en moyenne au gème jour post-opératoire et au 36ème jour post-traumatique. Il n'y eut ni déplacement du greffon ni récidive de la dislocation. Chez le patient décédé 6 mois après l'intervention opératoire, l'examen direct et histologique de la pièce opératoire montra l'incorporation et l'union des deux extrémités du greffon à l'os avoisinant avec, tout au long du ligament longitudinal postérieur, un pont d'os néoformé enjambant le défect corporéal. Ce type de spondylodèse semble avoir une place de choix dans le traitement et la rééducation de certains cas bien définis de tétraplégie traumatique. 


\section{ZUSAMMENFASSUNG}

6 Patientent mit einer akuten zervikalen traumatischen Querschnittsläsion wurden mit Körpektomie und ventraler interkorporaler Spondylodese mit Wadenbeinspan behandelt. Die erhaltene Stabilization ermöglichte eine schnellere Mobilization als mit der üblichen Streckbehandlung, mit Patienten ausser Bett durchschnittlich 9 Tage nach der Operation und 36 Tage nach dem Trauma. Es waren keine Spanverschiebung oder Luxationsrezidiv beobachtet. Bei dem Patienten, der am sechsten postoperativen Monate starb, zeigte die makroskopische und mikroskopische Untersuchung des Materials eine Vereinigung an den zwei Spanendpünkten. Dem Ligamentum longitudinale posterior entlang befand sich eine interkorporale Brücke, die sich aus neuformiertem Knochen bestand. In ausgewählten Fällen sieht es aus, dass die beschriebene Operation einen wichtigen Beitrag zur Behandlung und Rehabilitation von Patienten mit Querschnittslähmung bringt.

\section{General Discussion to Dr Rossier's Paper}

Prof. Weiss (Poland). We admitted in the last Io years 700 surgical cases and we made 320 anterior fusions trying different techniques, starting from Cloward going through fibula grafts and using now iliac crests as a rule. We are in this maybe particularly happy situation because we admit in the first 6 hours of cases and our surgery is made within 24 hours as a rule. We don't see any relationship between complications or death rate and surgery done. We do see around 20 per cent more neurological improvement as we have seen than on those previously completely conservatively treated cases. Now my point is concerned with our experience with fibula, when Nichol was in our place he suggested a fibula and we have made some 32 fibula grafts. Unfortunately we think that on fibula transplant it takes much longer as compared with the iliac crest graft.

Mr P. HARris (G.B.). I wonder Alain if in any of these patients you have seen that the dura has been torn and arachnoid torn? I have two patients where at operation CSF was leaking freely through the disintegrated disc tissue and was lying under the anterior column ligament which was almost completely torn through and very attenuated. Have you seen this?

DR Rossier. Not in these six patients, no. There is one thing I would like to insist on. None of the six patients was operated before the I2th post-injury day, because, contrary to what Marian Weiss said, I have evidence that morbidity and mortality are higher in initial acute cases until the patient stabilises his vital condition and especially his autonomic dysfunction. 